\title{
REKONDISI BEBERAPA UKURAN TUBUH TERNAK SAPI PERAH FRIESS HOLLAND DI BALAI PENGEMBANGAN BIBIT DAN PAKAN TERNAK TAMPUSU
}

\author{
Renaldo J. Maluhima, J.H. Manopo, A. Lomboan, S.H. Turangan \\ Fakultas Peternakan Universitas Sam Ratulangi Manado 95115
}

\begin{abstract}
ABSTRAK
Penelitian ini bertujuan untuk mengkaji keberhasilan rekondisi beberapa ukuran tubuh sapi FH yang mengalami rekondisi di Balai Pengembangan Bibit dan Pakan Ternak Tampusu. Ternak yang akan digunakan dalam penelitian ini adalah sapi perah Fries Holland $(\mathrm{FH})$ sebanyak 23 ekor yang berumur 7 bulan sampai 7 tahun dengan menggunakan metode penelitian deskriptif komparatif yaitu untuk membandingkan variabel yang sama untuk sampel yang berbeda yang selanjutnya menggunakan uji-t. Materi penelitian dengan mengukur bobot badan, lingkar dada, tinggi pundak dan panjang badan. Untuk pemeliharan menggunakan kandang ganda head to head, pakan yang diberikan adalah hijauan 10\%/ekor/hari dari berat badan dan konsentrat $2 \mathrm{Kg} / \mathrm{ekor} /$ hari. Ternak sapi perah di Tampusu Memiliki rata-rata bobot badan 401,533 $\pm 39,47 \mathrm{Kg}$ dengan nilai koefisien varias $9,8 \%$, rata-rata lingkar dada 174,12 $\pm 11,15 \mathrm{~kg}$ dengan nilai koefisien variasi $6,4 \%$, rata-rata tinggi pundak $136,47 \pm 9,16 \mathrm{~kg}$ dengan nilai koefisien variasi $6,7 \%$, rata-rata panjang badan $139,39 \pm 9,56 \mathrm{~kg}$ dengan nilai koefisien variasi $6,8 \%$. Berdasarkan hasil tersebut rekondisi sapi perah PFH di Balai Pengembangan Bibit dan Pakan Ternak Tampusu, terjadi kenaikan
\end{abstract}

*Korespondensi (corresponding author): Email: manopo_hendrik@yahoo.com terhadap bobot badan 11,68\%, lingkar dada $6,28 \%$, dan tinggi pundak $6,65 \%$.

Kata Kunci: Rekondisi, pengukuran tubuh, Sapi Perah Friess Holland,

ABSTRACT
COMPENSATORY
CONDITION OF SEVERAL
MEASURES IN FRIESS HOLLAND
DAIRY CATTLE AT TAMPUSU
ANIMAL FEED AND SEED
DEVELOPMENT CENTER. This
study was conducted to assess the compensatory condition of some body sizes of Friess Holland Dairy Cattle at Tampusu Animal Feed and Seed Development Center. Animals used in this study were 23 Friesian Fries Holland (FH) dairy cattle at aged of 7 months to 7 years old using a comparative descriptive research method by comparing the same variables for different samples and using the t-test. Research was done by measuring body weight, chest circumference, shoulder's height and body length. The maintenance of animals was using a double cage head to head. Feeds given were using forages of $10 \%$ / head / day from body weight. Concentrate was fed about $2 \mathrm{~kg} /$ head / day. Dairy cows in Tampusu have an average body weight of $401.533 \pm 39.47 \mathrm{Kg}$ with a varince coefficient value of $9.8 \%$, an average chest circumference of $174.12 \pm$ $11.15 \mathrm{~cm}$ with a varience coefficient value of $6.4 \%$, average shoulder height $136.47 \pm$ $9.16 \mathrm{~cm}$ with a variance coefficient value of $6.7 \%$, average body length $139.39 \pm$ $9.56 \mathrm{vm}$ with a variance coefficient of $6.8 \%$. Based on these results, the 
compensatory condition friess holland dairy cattle at tampusu animal feed and seed development center was increase body weight of $11.6 \%$, chest circumference $6.28 \%$ and shoulder height of $6.65 \%$.

Keywords: Compensatory condition, body measurements, Friess Holland Dairy Cattle,

\section{PENDAHULUAN}

Pengembangan peternakan di Indonesia bertujuan untuk mendapatkan pangan yang bergizi dan berdaya saing tinggi. Ternak sapi sebagai komoditi penghasil daging dan susu dapat diharapkan menjadi penopang dalam upaya pengembangan peternakan.

Permintaan bahan pangan asal ternak terutama produk susu, dewasa ini semakin meningkat seiring dengan semakin tingginya kesadaran masyarakat untuk hidup sehat. Namun, disisi lain produksi susu dan daging dalam negeri masih belum dapat memenuhi kebutuhan domestik.

Kondisi peternakan sapi perah di Indonesia saat ini semakin memprihatinkan. Kegiatan usaha peternakan sapi perah rakyat terlihat tidak mengalami perkembangan, bahkan mengalami kemunduran. Khususnya pada sapi perah Peranakan Fries Holland (PFH) yang mengalami rekondisi di balai pengembangan bibit dan pakan ternak desa Tampusu kecamatan Remboken, dimana sapi mengalami malnutrisi dalam waktu yang cukup lama, akibat dari hal tersebut ternak sapi FH mengalami penurunan produktivitas serta pertumbuhan dan perkembangan sapi FH. Keberlangsungan produksi dan tumbuh kembangnya dari sapi FH di Balai Pengembangan Bibit dan Pakan Ternak Tampusu dilakukan rekondisi pengukuran tubuh ternak seperti lingkar dada, tinggi pundak dan panjang badan, karena pengukuran tubuh ternak merupakan salah satu indikator untuk melihat produktivitas ternak dan untuk keperluan seleksi ternak.

Pertumbuhan dan perkembangan merupakan satu peristiwa tubuh ternak yang mengalami perubahan secara morfologi, besarnya perubahan tubuh baik bentuk maupun ukurannya sangat ditentukan oleh bangsa, umur, jenis kelamin dan pakan yang diberikan. Hal ini tentunya memberi dampak positif yakni terjadinya perbedaan ukuran tubuh masing-masing ternak, salah satu indikator untuk menilai pertumbuhan dan perkembangan tersebut adalah dengan mengukur peningkatan ukuran tubuh dengan indikator berupa lingkar dada, bobot badan, panjang badan dan tinggi pundak ternak.

Pertambahan bobot badan ternak dapat diketahui dengan cara menimbang, 
namun untuk penimbangan akan memerlukan waktu yang lama dan terdapat kesulitan apabila ternak yang dipelihara dengan kondisi kandang yang tidak memungkinkan. Untuk mempermudah penetapan bobot badan bisa dilakukan pengukuran lingkar dada dan panjang badan (winter, 1961). Bertambahnya ukuran tubuh maka bobot badan dari ternak juga akan bertambah. Oleh karena itu rekondisi sapi perah PFH di Balai Pengembangan Bibit dan Pakan Ternak Tampusu bertujuan untuk mengkaji keberhasilan rekondisi beberapa ukuran tubuh sapi FH yang mengalami rekondisi di Balai Pengembangan Bibit dan Pakan Ternak Tampusu.

\section{MATERI DAN METODE PENELITIAN}

Penelitian ini dilaksanakan di Balai Pengembangan Bibit dan Pakan Ternak Tampusu Kecamatan Remboken Kabupaten Minahasa selama bulan Juni sampai dengan bulan September 2018. Data yang diperlukan adalah data primer yang dilakukan pengukuran secara langsung terhadap setiap variabel. Setiap variabel diuji menggunakan t-test. Beberapa bagian yang diukur adalah bobot badan, lingkar dada, tinggi pundak dan panjang badan. Untuk pengukran bobot badan diukur dengan menggunakan rumus Winter (1961).

$$
\mathrm{BB}(\mathrm{kg})=\frac{L D^{2}(\mathrm{Cm}) \times \mathrm{PB}(\mathrm{Cm})}{10815,15}
$$

$$
\begin{aligned}
& \text { Keterangan ; } \\
& \text { BB = bobot badan } \\
& \text { LD = lingkar dada } \\
& \text { PB = panjang badan }
\end{aligned}
$$

\section{HASIL DAN PEMBAHASAN}

Data hasil pengukuran beberapa ukuran tubuh ternak sapi perah PFH dapat dilihat pada Tabel 1.

\section{Bobot Badan Sapi Perah PFH}

Hasil pengukuran bobot badan dapat dilihat pada Tabel 1 menunjukan bahwa rata-rata bobot badan yang dimiliki sapi perah PFH di balai pengembangan bibit dan pakan ternak Tampusu yaitu 401,53 \pm 39,74 Kg. Menurut Gumelar dan Aryanto (2011) standar ukuran yang ditentukan peraturan Direktur Jendral Peternakan Nomor: 07/PD.410/F/01/2008, yaitu 300 $\mathrm{kg}$ dan 307,68 $\pm 21,85$. Berdasarkan hasil penelitian untuk bobot badan setelah direkondisi mengalami kenaikan 11,68\%. Peningkatan bobot badan setelah direkondisi disebabkan karena pemberian hijauan dan konsentrat yang teratur sesuai dengan kebutuhan nutrien PFH. 
Tabel 1. Data Hasil Rekondisi Pengukuran Bobot Badan, Lingkar Dada, Tinggi Pundak dan Panjang Badan Sapi PFH

\begin{tabular}{|c|c|c|c|c|}
\hline \multirow[t]{2}{*}{ Variabel } & \multicolumn{2}{|c|}{ Rekondisi } & \multirow{2}{*}{$\begin{array}{l}\text { Standar } \\
\text { deviasi }\end{array}$} & \multirow{2}{*}{$\begin{array}{l}\text { Koefisien } \\
\text { keragaman }\end{array}$} \\
\hline & Sebelum & Sesudah & & \\
\hline Bobot badan $(\mathrm{Kg}) *$ & 359,53 & 401,53 & 39,47 & $9,8 \%$ \\
\hline Lingkar dada $(\mathrm{cm})^{*}$ & 163,82 & 174,12 & 11,15 & $6,4 \%$ \\
\hline Tinggi pundak $(\mathrm{Cm})^{*}$ & 128,21 & 136,74 & 9,16 & $6,7 \%$ \\
\hline Panjang badan $(\mathrm{cm})^{\mathrm{ns}}$ & 135,95 & 139,39 & 9,56 & $6,8 \%$ \\
\hline
\end{tabular}

Keterangan: *) berbeda nyata untuk setiap variable yang dihitung, ${ }^{\mathrm{ns}}$ ) tidak berbeda nyata untuk variable yang dihitung

Echols (2011) bobot badan dewasa tubuh akan terjadi ketika sel tubuh telah maksimal memproduksi protein tubuh sehingga terjadi peningkatan deposisi lemak. Peningkatan bobot badan diduga karena terjadi peningkatan lingkar dada karena lingkar dada erat hubungannya dengan pertambahan bobot badan sapi perah FH. Kidwell (1965) penafsiran yang paling tepat dalam pendugaan bobot hidup ternak sapi adalah melalui ukuran lingkar dada. Menurut Sulistyowati et al. (2009) bahwa bobot badan sapi perah sejak umur satu bulan dipengaruhi cukup kuat oleh lingkar dada dan panjang badan.

\section{Lingkar Dada}

Hasil pengukuran lingkar dada dapat dilihat Pada Tabel 1 yang menunjukkan ukuran rata-rata lingkar dada sapi perah PFH setelah mengalami rekondisi di balai pengembangan bibit dan pakan ternak Tampusu yaitu 174,12 \pm 17,63 Cm. Hasil ini secara signifikan lebih baik dibandingkan dengan sebelum direkondisi. Angka ini masih sesuai dengan sesuai dengan ukuran standar yang ditentukan Direktur Jenderal Peternakan Nomor: 07/PD.410/F/01/2008, yaitu $155 \mathrm{Cm}$ dan 157,23 \pm 3,88 (Gumelar dan Aryanto, 2011).

Berdasarakan hasil penelitian lingkar dada mengalami kenaikan sebesar $6,28 \%$. Menurut Tya (2016) bahwa antara pertambahan lingkar dada dengan pertumbuhan bobot badan memiliki hubungan yang sangat erat sehingga pertambahan lingkar dada yang dapat digunakan untuk menduga pertumbuhan berat badan. Permadi dan Aryanto (2011) menjelaskan bahwa ternak yang sedang tumbuh setiap pertumbuhan $1 \%$ lingkar dada diikuti oleh kenaikan bobot hidup sebesar 3\%. Cook et al. (1961) bahwa ukuran lingkar dada dan lingkar perut mempunyai korelasi yang tinggi dengan 
bobot hidup dibanding dengan ukuranukuran lainnya.

\section{Tinggi Pundak}

Tabel 1 menunjukkan rata-rata tinggi pundak sapi perah PFH di balai pengembangan bibit dan pakan ternak Tampusu yaitu $136,47 \pm 9,16 \mathrm{Cm}$. Angka tersebut memiliki rata-rata di atas standar ukuran yang ditentukan oleh peraturan Direktur Jenderal Peternakan Nomor: 07/PD.410/F/01/2008, yaitu $115 \mathrm{Cm}$. Menurut Gumelar dan Aryanto (2011) bahwa tinggi pundak sapi perah $\mathrm{PFH}$ berkisar $121,63 \pm 3,28$. Ukuran tinggi pundak sapi perah PFH di balai pengembangan bibit dan pakan ternak Tampusu setelah direkondisi mengalami peningkatan sebesar $6,65 \%$. Peningkatan ini seiring dengan meningkatnya bobot badan serta lingkar dada. Hal itu dipertegas oleh Sugeng (1993) bahwa ada korelasi yang nyata antara bobot badan, lingkar dada, panjang badan serta tinggi pundak sapi perah. Faktor-faktor yang mempengaruhi tinggi pundak diantaranya adalah karena pengaruh manajemen pemberian pakan, genetik, serta kondisi ternak itu sendiri (Makin 2011), yang diperkuat dengan nilai heritabilitas tinggi pundak terhadap ukuran kerangka sapi (frame score) memiliki nilai yang tinggi pada umur sapi 15 bulan yaitu 0,75 (Vargas et al., 2000)

\section{Panjang Badan}

Hasil yang diperoleh dari pengukuran panjang badan pada Tabel 1 yakni rata-rata 139,39 \pm 9,56 $\mathrm{Cm}$, angka tersebut lebih tinggi dari rata-rata panjang badan yaitu $125 \mathrm{~cm}$ dan $127,92 \pm 3,11 \mathrm{~cm}$ (Gumelar dan Aryanto, 2011). Angka tersebut sesuai dengan angkat rata-rata dari variable lainnya karena ada korelasi antara bobot badan, lingkar dada, tinggi pundak dan panjang badan (Sugeng, 1993).

Hasil dari pengukuran panjang badan tidak berpengaruh pada rekondisi PFH di Balai Pengembangan Bibit dan Pakan Ternak Tampusu. Hal ini disebabkan karena sapi perah yang ada rata-rata sudah berumur dewasa serta sudah melewati batas umur pertumbuhan. Zainudin et al. (2015) menjelaskan bahwa dengan bertambahnya umur maka kondisi tubuh ternak secara fisiologis berupa kemampuan otot, tulang serta jaringan sudah melemah dan disertai dengan kerusakan sel-sel yang cepat.

\section{KESIMPULAN}

Berdasarkan hasil pembahasan dapat disimpulkan bahwa rekondisi sapi perah Peranakan Friess Holland di Balai Pengembangan Bibit dan Pakan Ternak Tampusu, terjadi kenaikan terhadap bobot 
badan $11,68 \%$, lingkar dada $6,28 \%$, dan

tinggi pundak $6,65 \%$.

\section{DAFTAR PUSTAKA}

Cook, A.C., M.K. Kohli and W.M. Dawson. 1961. Relationship of dessing procentage in milking shirthom steer. Jurnal Animal Science 10: 386-391

Echols, A. C. 2011. Relationships Among Lifetime Measures of Growth and Frame Size for Commercial Beef Females in a Pasture-Based Production System in the Appalachian Region of the United States. [Tesis]. Faculty of Animal and Poultry Sciences. Virginia Polytechnic Institute, USA.

Kidwell, J. P. A. 1965. Study of the relation between body conformation and carcass wuality.in fat calves. J Anim. Sci, 14 : 233-242

Makin, M. 2011.Tatalaksana Peternakan Sapi Perah. Edisi pertama. Graha Ilmu Yogyakarta.

Permadi, A.G. dan R. Aryanto. 2011. Bobot badan dan ukuran tubuh sapi perah betina Fries Holland di wilayah kerja koperasi peternak garut selatan. J. Buana Sains, 11 (2): 163-170.
Sugeng. 1993. Hubungan Bobot Badan Dengan Lingkar Dada, Tinggi Pundak, Dan Panjang Badan Sapi Perah. Buletin Peternakan. Jakarta.

Sulistyowati, E., E. Kuswadi, L. Sutarno, dan G. Tampubolon. 2009. Reproduction performance of FH dairy cows and their calves aging 1- 3 Months- case study: Air duku dan Desa Air Putih Kali Bandung Villages, Selupu Rejang, Rejang Lebong, Bengkulu. Jurnal Sain Peternakan Indonesia Vol. 4(1): 21-26

Tya, M. 2016. Hubungan antara pertambahan ukuran-ukuran tubuh dengan pertambahan bobot badan sapi bali betina Di Ptpn VI Provinsi Jambi. Jurnal Universitas Jambi. Vol 1 hal 7.

Vargas, C.A., M. A. Elzo, C. C. Chase, P. J. Chenoweth, and T. A. Olson. 2000. Genetic parameters and relationships between hip height and weight in brahman cattle. J. Anim. Sci.78:3045-3052

Winter, L. M. 1961.Introduction to Breeding Farm Animal. Jhon Wiley and Sons inc, New York.

Zainudin, M., M.N. Ihsan, Suyadi. 2015. Efisiensi PFH reproduksi sapi perah pada berbagai umur di CV. Milkindo Berka Abadi Desa Tegalsari Kecamatan Pekanjen Kabupaten Malang. J. Ilmu-ilmu Peternakan, 24 (3): 32-37. 